\title{
Centralne zaburzenia przetwarzania słuchowego a problemy w nauce u uczniów klasy II Szkoły Podstawowej
}

\section{Correspondence between central auditory processing disorders and learning difficulties of $2^{\text {nd }}$ grade students of elementary school}

\author{
Beata Statuch, Zdzisław Marek Kurkowski \\ Zakład Logopedii i Językoznawstwa Stosowanego UMCS, Lublin
}

Adres autora: Zakład Logopedii i Językoznawstwa Stosowanego UMCS, ul. Sowińskiego 17, 20-040 Lublin, e-mail: brawurka1718@interia.pl

\section{Streszczenie}

Wstęp: Zaburzenia percepcji słuchowej nie tylko mogą utrudniać bądź uniemożliwiać dziecku dostęp do informacji dźwiękowej, ale zakłócić również rozwój mowy, a w konsekwencji negatywnie wpływać na funkcjonowanie dziecka w szkole. Istnieje pewna grupa dzieci, które pomimo prawidłowej czułości słuchu, mają trudności ze słuchaniem i komunikowaniem się. Trudności w nauce, w pisaniu i czytaniu oraz często współwystępujące z nimi zaburzenia emocjonalne wynikają często z zaburzenia przetwarzania dźwięków na poziomie centralnym.

Cel: Głównym celem pracy było poznanie zależności jakie występują między centralnymi zaburzeniami przetwarzania słuchowego u dzieci a ich problemami w nauce.

Materiał: W badaniu uczestniczyło 20 osób - uczniów klasy II Szkoły Podstawowej. Badani uczniowie to dzieci w normie intelektualnej oraz w normie słuchowej. W badanej grupie było 10 dziewczynek i 10 chłopców.

Metoda: W niniejszej pracy wykorzystano następujące techniki badawcze: testy centralnych funkcji słuchowych DLF, DLI i FPT, oceniające progi dyskryminacji zmian wysokości, głośności i różnicowania sekwencji częstotliwości. Ponadto wykorzystano Test Rozdzielnousznego Słyszenia, Test odtwarzania struktur rytmicznych M. Stambak, Logopedyczny Test Przesiewowy, Skalę Zachowań Słuchowych (SAB) oraz Test SPN i aSPN. Wychowawca miał za zadanie wypełnić ankietę dotyczącą trudności w nauce u uczniów.

Wyniki: Przeprowadzone badania potwierdziły zależność występowania problemów w nauce z centralnymi zaburzeniami słuchu u uczniów II klasy Szkoły Podstawowej. Najczęściej zaburzone procesy u badanych uczniów to różnicowanie częstotliwości i rozumienie mowy w szumie. To z kolei wpływa na problemy z nauką - niemal 40\% uczniów ma trudności w uczeniu się.

Wnioski: Uzyskane wyniki potwierdzają wysoki odsetek występowania zaburzeń centralnych funkcji słuchowych u dzieci oraz towarzyszącym im trudnościom w nauce.

Słowa kluczowe: $(\mathrm{C}) \mathrm{APD} \bullet$ trudności w nauce $・ \mathrm{DLF} \bullet \mathrm{DLI} \bullet \mathrm{FPT}$

Abstract

Background: Hearing impairment is not only affect or impossible the child access to sound information but also disturb the speech development and, consequently, have a negative effect the functioning of the child in school. There is a group of children, who despite normal hearing sensitivity, they have difficulties in listening and communicating. Learning difficulties in reading and writing and often coexisting with them emotional disorders often result from disorders processing of sounds at the central level.

Aim: Main objective on this study was research on how central auditory processing disorders and learning difficulties are related. 
Material: Study includes 20 participants $2^{\text {nd }}$ grade students of elementary school of normal intellectual capacity and not affected by any hearing loss. In the study group was 10 girls and 10 boys.

Method: Following research tools were used in the study: central auditory functions test DLF, DLI and FPT, that determine discrimination thresholds of pitch, volume and differentiation sequence of frequency. Moreover, the use: Dichotic Listening Test, Test playing rhythm structures M. Stambak, Logopedics Screening Test, Scale of Auditory Behaviors (SAB) as well as Speech in Noise Test (SPN) and Adaptive Speech in Noise (aSPN). Teacher had complete a questionnaire about learning difficulties in students..

Results: Research confirmed that there is clear link between the occurrence of (C)APD and learning difficulties in $2^{\text {nd }}$ grade students of elementary school. The most disturbed processes in the examined students were pitch discrimination and understanding speech in noise. This in turn affects the learning difficulties - almost $40 \%$ of pupils have learning difficulties.

Conclusions: The results confirmed the high percentage of children with central auditory disorders and the accompanying learning difficulties.

Key words: $(\mathrm{C}) \mathrm{APD} \bullet$ learning difficulties $\bullet \mathrm{DLF} \bullet \mathrm{DLI} \bullet \mathrm{FPT}$

\section{Wstęp}

Według Amerykańskiego Towarzystwa Mowy, Języka i Słuchu (ASHA) można postawić rozpoznanie centralnych zaburzeń przetwarzania słuchowego ([C]APD), jeżeli co najmniej jedna $z$ poniżej przedstawionych wyższych funkcji słuchowych jest zaburzona: 1) lokalizacja źródła dźwięku, 2) różnicowanie dźwięków, 3) rozpoznawanie wzorców dźwięków, 4) analiza czasowych aspektów sygnału dźwiękowego obejmująca: rozdzielczość czasową, maskowanie poprzedzające i następowe, integrację czasową, percepcję kolejności dźwięków, 5) umiejętność rozmienia mowy zniekształconej, 6) umiejętność rozumienia mowy w obecności sygnału zagłuszającego [Senderski, 2002]. Według Jerger’a i Musiek’a (2000) ośrodkowe procesy przetwarzania słuchowego mogą być ogólnie zdefiniowane jako deficyt $\mathrm{w}$ przetwarzaniu informacji swoistych dla słuchu. Deficyt ten może nasilać się w niekorzystnym środowisku akustycznym. Może przejawiać się jako trudności w słyszeniu, zrozumieniu mowy, rozwoju języka oraz uczeniu się. W czystej formie jednakże jest on rozumiany jako deficyt w przetwarzaniu sygnału słuchowego [Fuente, McPherson, 2007].

Musiek (1997) szacuje częstość występowania centralnych zaburzeń słuchu na $2 \%$ do $3 \%$ populacji dzieci w wieku 5-10 lat, dwa razy częściej u chłopców. Co najmniej u połowy dzieci (2-5\% populacji w wieku szkolnym) z rozpoznanymi trudnościami w uczeniu się, dysleksją, zespołem zaburzeń uwagi i zachowania występują zaburzenia przetwarzania słuchowego. W wielu przypadkach w tej grupie dzieci to właśnie trudności słuchowe są przyczyną opóźnień w nauce, trudności w czytaniu i pisaniu czy zaburzeń zachowania [Senderski, 2002].

Według Jerger’a (1993) istnieją trzy główne przyczyny (C)APD u dzieci: 1) 75\% przypadków to zaburzenia neuromorfologiczne na poziome komórkowym w obrębie lewej półkuli i/lub spoidła wielkiego (dysplazja, ektopie itp.); 2) $25 \%$ to zaburzenia opóźnionego dojrzewania OUN; 3 ) $>5 \%$ makroskopowe uszkodzenia układu nerwowego [Senderski 2010]. Problem w uczeniu się wynika prawdopodobnie głównie z niesprawności w efektywnym wykorzystaniu informacji językowej lub słuchowo-językowej. Nie wiadomo, czy specyficzne problemy słuchowe są przyczyną zaburzeń przyswajania języka, czy też ich następstwem [Kurkowski 1999].
Pacjenci z podejrzeniem upośledzenia wyższych czynności słuchowych nie są zdolni do prawidłowego funkcjonowania w zdegradowanym akustycznie środowisku, w obecności szumu tła oraz pomieszczeniach z długim czasem pogłosu. U uczniów przekłada się to na niezdolność do prawidłowego odbioru informacji przekazywanych werbalnie w warunkach klasy, a przez to na osiągnięcia edukacyjne. Uczniowie ci, mimo prawidłowych wyników badań audiometrii tonalnej i testów elektrofizjologicznych, sprawiają często wrażenie osób niedosłyszących. To właśnie niemożność prawidłowego rozumienia mowy w zdegradowanym akustycznie środowisku jest objawem kluczowym dla upośledzonego centralnego przetwarzania słuchowego [Śpiewak B., Śpiewak P., 2007]. Objawom opisanym powyżej towarzyszą zwykle trudności w skupianiu uwagi słuchowej i jej łatwa przerzutność. Równie często spotykamy w tych przypadkach zaburzenia lokalizacji dźwięków. Dość trudno i rzadko rozpoznawalnym objawem centralnych zaburzeń słuchu jest wyraźne zmniejszenie rozumienia i odczuwania muzyki. Zwłaszcza muzyka poważna jest przez tego rodzaju osoby traktowana jako coś zupełnie bez sensu [Zaleski, 1993a]. Dzieci wykazujące objawy centralnych zaburzeń słuchu mają najczęściej gorsze wyniki postępów w szkole, niż by to wynikało z ich ilorazów inteligencji. Ponadto dzieci te wykazują braki w umiejętności skupiania uwagi słuchowej, mają trudności w rozpoznawaniu fonemów droga słuchową i zwykle piszą dyktanda w sposób wysoce niezadowalający [Zaleski, 1993b].

Wiele dzieci z (C)APD ma problemy z czytaniem, słabiej literuje i gorzej pisze ręcznie. Mogą one mieć zaburzenia artykulacji oraz problemy językowe. W klasie mogą ujawniać frustracje wynikające $z$ deficytów percepcyjnych lub mogą być nieśmiałe czy pozostawać na uboczu z powodu niskiej samooceny, wynikającej z licznych niepowodzeń. Te przykłady nie wyczerpują wszystkich zachowań związanych z (C)APD. Nie każde dziecko z zaburzeniami procesów przetwarzania ujawnia wszystkie wymienione zachowania. Liczba problemów doświadczonych przez dziecko wynika z nasilenia niezdolności do uczenia się ze słuchu [Keith 2005].

Osobnym problemem jest odróżnienie dzieci z zaburzeniami uwagi (ADD, ADHD) od dzieci z ośrodkowymi zaburzeniami słuchu. Łatwo jest pomylić (C)APD z ADHD (zwłaszcza typu z deficytem uwagi), jako że oba schorzenia mogą współwystępować i charakteryzować się takimi 
samymi objawami: 1) problemami z koncentracją; 2) problemami z odróżnianiem dźwięków głównych od dźwięków tła; 3) problemami z wykonywaniem serii poleceń [Kutcher, Attwood, Wolff, 2007]. Pewne kryteria diagnostyczne zaburzeń uwagi („łatwo się rozprasza”, „nie skupia się na zadaniu” oraz „wydaje się, że nie słucha”) są wspólne dla ośrodkowych zaburzeń słuchu. Aby właściwie postawić diagnozę potrzebna jest współpraca audiologa i psychologa. Postawienie prawidłowej diagnozy jest bardzo istotne, gdyż w obu schorzeniach stosuje się inne metody terapeutyczne [Senderski, 2007].

Wiele osób u których występują objawy (C)APD ma inne zaburzenia towarzyszące np.: obwodowy ubytek słuchu, trudności w uczeniu się, zaburzenia ze spektrum autyzmu, zaburzenia lub opóźnienia mowy i języka, zaburzenia deficytu uwagi z lub bez nadpobudliwością ruchową - ADHD, ADD, spadek funkcji poznawczych związany ze starzeniem się itp. Obecność jednego lub więcej zaburzenia współwystępującego u danego pacjenta, może mieć wpływ na wyniki badań behawioralnych i elektrofizjologicznych [Baran, 2007].

\section{Cel}

Celem przeprowadzonych badań było poznanie zależności jakie występują między centralnymi zaburzeniami przetwarzania słuchowego u dzieci w wieku szkolnym a ich problemami w nauce.

\section{Metoda badania}

W badaniu uczestniczyło 20 uczniów II klasy Szkoły Podstawowej w Sandomierzu. Wcześniej u uczniów przeprowadzone były przesiewowe badania słuchu, składające się $\mathrm{z}$ audiometrii tonalnej. Dzieci, które miały negatywny bądź wątpliwy wynik audiometrii tonalnej zostały wyłączone z badania. Kolejność przeprowadzonych badań była jednakowa dla każdego ucznia. Pierwszy blok badań zawierał: Test Rozdzielnousznego Słyszenia (słowny), Test Różnicowania Sekwencji Częstotliwości (Frequency Pattern Test), Test odtwarzania struktur rytmicznych M. Stambak oraz Logopedyczny Test Przesiewowy. Drugi blok badań zawierał testy audiologiczne z programu APD: DLF, SPN, DLI, aSPN. Opiekunowie dzieci, wypełnili Skale Zachowań Słuchowych (Scale of Auditory Behavior). Wychowawca - nauczyciel nauczania zintegrowanego miał za zadanie wypełnić ankietę dotyczącą trudności w nauce dziecka.

Test Rozdzielnousznego Słyszenia (TRS) jest narzędziem diagnostycznym, mającym na celu ustalenie półkuli dominującej w percepcji dźwięków mowy. Wyodrębnienie półkuli dominującej umożliwia określenie profilu lateralizacji. Test ten pozwala również dokonać oceny przebiegu koordynacji (integracji) czynności percepcyjnych i motorycznych biorących udział w procesach komunikacji językowej (słuchaniu, mówieniu, czytaniu i pisaniu). Badanie to polega na jednoczesnym prezentowaniu różnych dźwięków osobno dla ucha prawego i lewego. Dziecko słyszy jednocześnie pary wyrazów np. pas - pal, tan - ton, but - bat, jego zadaniem jest powtórzenie wyrazów które zapamiętało. Najlepiej, aby uchem dominującym było ucho prawe, co wynika z teorii lewopółkulowej lateralizacji odbioru mowy na poziomie mózgu.
Test Różnicowania Sekwencji Częstotliwości (FPT) obejmuje prezentację trzech tonów z których jeden różni się od pozostałych wysokością. Ton wysoki ma częstotliwość $1122 \mathrm{~Hz}$ a ton niski $880 \mathrm{~Hz}$. Podczas testu osoba badana słyszy w przypadkowej kolejności 30 sekwencji tonów. Zadaniem osoby badanej jest powtórzenie słyszanej sekwencji werbalnie.

Test odtwarzania struktur rytmicznych M. Stambak służy do oceny poziomu rozwoju percepcji słuchowej, ponieważ przyjęto założenie, że słowa stanowią struktury rytmiczno-czasowe. Badający wystukuje ołówkiem strukturę rytmiczną $\mathrm{z}$ pewnymi przerwami. $\mathrm{W}$ teście jest 21 różnych układów rytmicznych ułożonych zgodnie z zasadą stopniowania trudności.

Logopedyczny Test Przesiewowy dla Dzieci w Wieku Szkolnym jest przeznaczony do oceny sprawności językowych i komunikacyjnych.

Testy DLF, DLI, SPN i aSPN zostały wykonane za pomocą programu komputerowego APD (Auditory Processing Disorder). Test DLF (Difference Limen of Frequency) pomaga określić próg dyskryminacji zmian wysokości dźwięku. Procedura badania DLF wygląda następująco: słuchaczowi prezentowane są dwa następujące po sobie tony, różniące się nieznacznie częstotliwością, bądź nie. Zadaniem słuchacza jest określenie czy podane dźwięki były różne czy takie same. Test zdolności różnicowania głośności (Difference Limen of Intensity) przeprowadza się dla ustalenia najmniejszej zmiany natężenia, jaka może być rozpoznana przez pacjenta. Wyniki są wyrażone $\mathrm{w} \mathrm{dB}$, jest to próg najmniejszej różnicy w intensywności jaką słuchacz potrafi wykryć. Procedura badania wygląda podobnie jak w DLF, $\mathrm{z}$ tą różnicą, że podawane dźwięki różnią się intensywnością. Słuchacz ma powiedzieć kiedy prezentowane dźwięki są różne (gdy głośność dwóch tonów jest inna). Test SPN (Speech in Noise) polega na rozumieniu mowy w szumie. Słowa prezentowane są na tle tzw. babble noise - szumu maskującego. Szum jest na stałym poziomie, a słowa są sygnałem zmiennym. Intensywność dźwięku wynosiła $50 \mathrm{~dB}$, minimalny stosunek sygnału do szumu (SNR) wynosił 0 dB, $50 \%$ poprawnie zidentyfikowanych wyrazów świadczą o pozytywnym zaliczeniu testu. Test jest stosowany do określenia zdolności rozumienia mowy na tle szumu. Test aSPN (Adaptive Speech in Noise) wyznacza poziom progu SNR.

Zadaniem rodziców było uzupełnienie Skali Zachowań Słuchowych, która został przetłumaczona z języka angielskiego i zaadaptowana do polskich warunków przez autorkę pracy. Scale of Auditory Behaviors (SAB) to kwestionariusz stworzony przez Conlin'a, (2003). SAB jest bardzo prostą techniką diagnostyczną, której celem jest wczesne wykrywanie symptomów wskazujących na możliwość wystąpienia (C)APD, czyli centralnych zaburzeń przetwarzania słuchowego. Zwraca ona uwagę rodziców i nauczycieli na zachowania dziecka, które sygnalizują obecność dysharmonii w rozwoju psychoruchowym, szczególnie opóźnień w rozwoju funkcji słuchowych. Skala Zachowań Słuchowych ma formę kwestionariusza, który zawiera 12 stwierdzeń dotyczących różnych symptomów ryzyka wystąpienia (C)APD. Kwestionariusz ten pozwala jakościowo oraz ilościowo opisać problemy ucznia, które mogą wskazywać na ryzyko wystąpienia (C)APD. 
Test Różnicowania Sekwencji Częstotliwości (FPT)

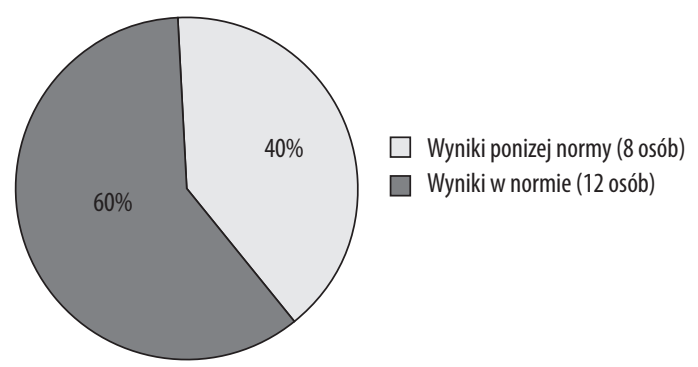

Test odtwarzania struktur rytmicznych M. Stambak

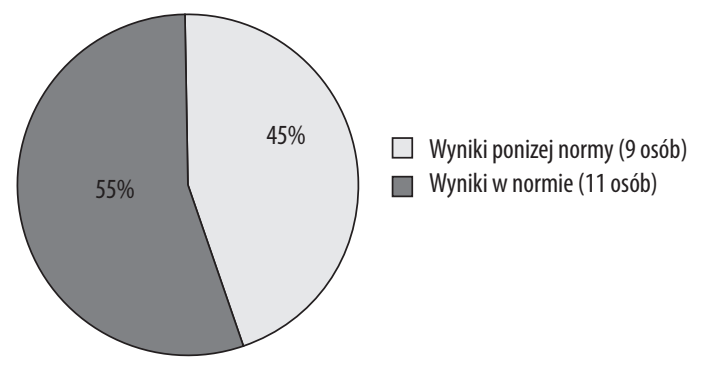

Rycina 1. PrzedstawieniegraficznewynikówTestuRóżnicowania Sekwencji Częstotliwości i Testu odtwarzania struktur rytmicznych M.Stambak

Zastosowano również autorską ankietę, która dotyczyła trudności w nauce badanych uczniów. Skierowana ona była do wychowawcy klasy - nauczyciela nauczania zintegrowanego. Pytania dotyczyły rodzaju występujących trudności, poprawności wymowy oraz umiejętności szkolnych. Nauczyciel miał za zadanie zaznaczyć odpowiedź TAK lub NIE w przypadku pytań dotyczących występowania trudności w ujęciu ogólnym oraz trudności, które zostały wyszczególnione: czytanie, pisanie, liczenie, nauka języka obcego, wymowa. Ponadto miał ocenić umiejętności szkolne w skali od 1 do 5 (5 - umiejętności bardzo dobre, 4 - dobre, 3 - dostateczne, 2 - zadowalające, 1 - niewystarczające).

\section{Wyniki}

Analiza wyników badań potwierdza zależność występowania problemów w nauce $\mathrm{z}$ centralnymi zaburzeniami słuchu. W badaniach centralnych zaburzeń przetwarzania słuchowego przeprowadzonych w grupie 20 uczniów klasy II Szkoły Podstawowej uzyskano wyniki, które potwierdzają duże trudności w tym zakresie. Z zestawienia ze sobą wyników badania testem FPT i Testem odtwarzania struktur rytmicznych M. Stambak wynika, że wśród uczniów mających problem podczas rozwiązywania testu FPT, niemal każdy miał również problem z odtworzeniem struktur rytmicznych (Rycina 1). Testy te mogą być stosowane zamiennie, gdyż dają podobne wyniki. Duża zależność występuje także pomiędzy wynikami testu FPT oraz testu DLF. Test FPT błędnie rozwiązało 40\% badanych, a test DLF 50\% badanych. Wystąpiła tu istotna zależność - wszystkie osoby, które miały trudności z rozwiązaniem testu FPT, miały je także w teście DLF. Zaskakujący jest fakt, iż nie wykryto istotnej zależności pomiędzy wynikami testów DLF
Lateralizacja słuchowa dzieci

Lateraliacja słuchowa dzieci

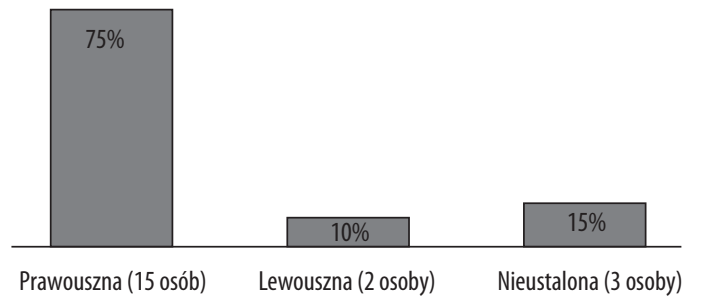

Rycina 2. Graficzne przedstawienie wyników Testu Rozdzielnousznego Styszenia

Występowanie trudności w nauce u badanych dzieci

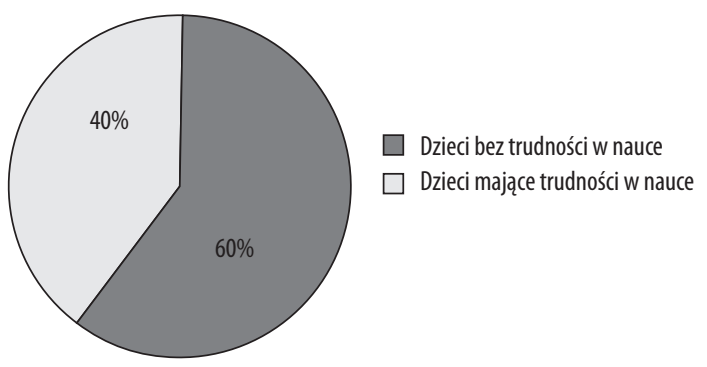

Rycina 3. Wykres obrazujący liczbę dzieci, które mają trudności w nauce

i DLI. Świadczy to o tym, że niska zdolność różnicowania częstotliwości nie wpływa na zdolność różnicowania głośności i odwrotnie - jeśli ktoś ma problemy z różnicowaniem głośności nie musi ich mieć przy różnicowaniu częstotliwości. Ocena progu dyskryminacji głośności dźwięku nie stanowiła dla dzieci tak dużego problemu jak określenie progu dyskryminacji zmian wysokości dźwięku. Wiele dzieci miało problemy z prawidłowym rozwiązaniem testów rozumienia mowy w szumie (SPN i aSPN). Wśród badanych były i takie osoby, które miały błędne wyniki tylko w jednym z powyższych testów. Dlatego stosowanie tych testów zamiennie, może być nieskuteczne, a wyniki niejednoznaczne. Najlepiej jest wykonać całą gamę dostępnych nam testów rozumienia mowy w szumie.

Za pomocą Testu Rozdzielnousznego Słyszenia stwierdzono, że większość, bo aż 75\% dzieci (15 osób) wykazuje przewagę ucha prawego, a $10 \%$ badanych ( 2 osoby) wykazują przewagę ucha lewego. Natomiast 3 dziewczynki (15\%) mają nieustaloną lateralizację (Rycina 2). Duża część badanych dzieci - 7 osób (35\%) - wykazuje opóźnienia w stosunku do norm rozwojowych podanych przez autora testu.

Chcąc sprawdzić czy centralne zaburzenia przetwarzania słuchowego wpływają na sprawności językowe i komunikacyjne badanych dzieci, wykorzystano Przesiewowy Test Logopedyczny dla Dzieci w Wieku Szkolnym. Wyniki badań wykazały ścisły związek pomiędzy (C)APD a problemami językowymi u dzieci. Osoby, które miały niskie wyniki $\mathrm{w}$ badaniach centralnych funkcji słuchowych, miały także niski wynik w Logopedycznym Teście Przesiewowym. W sumie wyniki niezadowalające otrzymało 30\% dzieci. 
Za pomocą kwestionariusza SAB (Skala Zachowań Słuchowych) rodzice jakościowo oraz ilościowo opisali problemy ucznia, które mogą wskazywać na ryzyko wystąpienia (C)APD. Zdaniem rodziców 30\% dzieci wykazywało zachowania mogące sugerować zaburzenia centralnego przetwarzania słuchowego. A $\mathbf{z} 5 \mathrm{z}$ nich (25\%) wykazywało trudności w nauce. Według wychowawcy klasy - nauczycielki nauczania zintegrowanego trudności w nauce ma 8 uczniów, co stanowi 40\% badanych (Rycina 3).

\section{Podsumowanie}

Na podstawie wyników przeprowadzonych badań można stwierdzić, iż centralne zaburzenia przetwarzania słuchowego mają duży wpływ na problemy w nauce oraz ogólne funkcjonowanie dziecka w szkole. Uczniowie, którzy mieli zaburzone niemal wszystkie wyższe funkcje słuchowe stanowili $10 \%$ badanych. Jest to wynik większy od podawanego w literaturze przedmiotu. Najczęściej zaburzone procesy u badanych uczniów to różnicowanie częstotliwości i rozumienie mowy w szumie. Dzieci, które osiągały niezadowalające wyniki w badaniach centralnych funkcji słuchowych, miały także niską sprawność językową i komunikacyjną. To z kolei wpływa na problemy z nauką - niemal $40 \%$ uczniów ma trudności w uczeniu się. Badane dzieci, zdaniem rodziców: często prosiły o powtórzenie informacji, łatwo się rozpraszały, głośno nastawiały telewizor, nie potrafiły dłużej skoncentrować się przy odrabianiu lekcji, co w większości przypadków przekładało się na słabe oceny w szkole, które ma aż 35\% badanych. Opiekunowie i nauczyciele czasem nie potrafią zakwalifikować problemu, który występuje u tych dzieci. Często są one uważane za leniwe i niegrzeczne, bo nie potrafią skupić się na lekcji i niewiele informacji z niej wynoszą.

Uzyskane wyniki potwierdzają wysoki odsetek występowania zaburzeń centralnych funkcji słuchowych u dzieci. Wydaje się głęboko uzasadnionym wprowadzenie jako rutynowych badań, testy które mają na celu sprawdzenie wyższych funkcji słuchowych u dzieci w wieku szkolnym. Ważne jest poinformowanie rodziców i nauczycieli o cechach charakterystycznych dla centralnych zaburzeń przetwarzania słuchowego oraz sposobach postępowania z dziećmi z tego rodzaju zaburzeniami. Należy zmodyfikować sposoby nauczania w szkole i w domu, prowadzić trening słuchowy w tradycyjny sposób jak i przy użyciu programów komputerowych. Pomocne może być także zastosowanie urządzeń wspomagających słyszenie (systemy FM) w celu poprawienia stosunku sygnału do szumu podczas zajęć szkolnych.

\section{Piśmiennictwo:}

1. Baran J.A.: Test battery considerations. (W:) Musiek F.E., Chermak G.D. (red.). Handbook of (Central) Auditory Processing Disorder. Vol. I, 2007. San Diego, Oxford, Brisbane: Plural Publishing Inc., 2007; 163-92

2. Fuente A., McPherson B.: Ośrodkowe procesy przetwarzania słuchowego: wprowadzenie i opis testów możliwych do zastosowania u pacjentów polskojęzycznych. Otolaryngologia, 2007; 6(2): 66-67

3. Keith R.W.: Zaburzenia procesów przetwarzania słuchowego. (W:) Śliwińska- Kowalska M. (red.). Audiologia kliniczna. Łódź: Oficyna wydawnicza Mediton, 2005; 367-75

4. Kurkowski Z.M.: Centralne zaburzenia percepcji słuchowej. Słyszę, 1999; 3(17): 7-8

5. Kutcher M.L., Attwood T., Wolff R.R.: Dzieci z zaburzeniami łączonymi. ADHD, trudności w nauce, zespół Aspergera, zespół Touretta, depresja dwubiegunowa i inne zaburzenia. Warszawa: Wyd. Liber, 2007; 215-27
6. Senderski A.: Diagnostyka centralnych zaburzeń przetwarzania słuchowego. Algorytm postępowania diagnostycznego. 2002; http://dokumenty.ifps.org.pl/senderski2.pdf

7. Senderski A.: Ośrodkowe zaburzenia słuchu u dzieci w wieku szkolnym - materiały informacyjne. Warszawa: Instytut Fizjologii i Patologii Słuchu, 2007

8. Senderski A.: Ośrodkowe zaburzenia słuchu (II). Słyszę, 2010; 5/115: 4-8

9. Śpiewak B., Śpiewak P.: Audiometria mowy w szumie u dzieci $\mathrm{z}$ trudnościami w nauce uwarunkowanymi nieprawidłowym rozwojem języka. Otolaryngologia, 2007; 6(3): 151-56

10. Zaleski T.: Centralne zaburzenia słuchu. Logopedia, 1993a; 20: 181-87

11. Zaleski T.: Rozpoznawanie zaburzeń słuchu pochodzenia centralnego. Audiofonologia, 1993b; V: 85-89 